\title{
Socio-Economic Impact of Unemployment Among the Youths in the FCT, Abuja-Nigeria: A Case Study of Abaji Area Council
}

\author{
Ekpetere O. Kenneth $^{1^{*}}$ Ekeh O. Faith ${ }^{2 *}$ \\ 1. Department of Geography and Environmental Management, University of Abuja, PMB117, Abuja, Nigeria \\ 2. Department of Botany, Faculty of Biological Sciences, Nnamdi Azikiwe University, Nigeria
}

\begin{abstract}
The research investigated the socio-economic impact of unemployment among the youths in the Federal Capital City of Abuja-Nigeria: using Abaji Area Council as a case study. The research also examines; the Socio-economic characteristic of the youths in Abaji Area Council; trend of unemployment rate; factors responsible for the unemployment as well as the effects of unemployment among the youths in the study area. Data were derived directly from the field using questionnaire administration method as well as field interview. At the end of the research, it was revealed that; lack of technical know-how, political affiliations, population explosion amongst others were the main causes of unemployment among the youths in Abaji Area Council. The study also showed that; increased crime rates, pressure on infrastructures and basic amenities, hunger and poverty, loss of confidence towards the government and social vices are consequences of youth unemployment in the study area. Recommendations were proffered which include; tax reduction and tax holidays for production plants to reduce operating costs; reformation of educational system; ensuring graduates learn more practical issues and problems than theories; encourage vocational trainings in Abaji Area Council and empowering the youth; reforming the agricultural sector through modernization to attract graduates; investing in the industrial sector to increase capital formation and Growth of small and medium scale industries by the Government, amongst others.
\end{abstract}

Keywords: Youth unemployment, industry, agriculture, economic activities, population explosion, political affiliations, social vices, policies, infrastructures, amenities, tax, Abaji Area Council, Federal Capital Territory.

DOI: $10.7176 / \mathrm{JEES} / 9-6-13$

Publication date:June $30^{\text {th }} 2019$

\section{INTRODUCTION}

Global youth unemployment has been high for a decade, with an estimated 73 million young people age $15-24$ jobless in 2013 (United Nations, 2013). Worrying economic recovery from the global recession and financial crisis has not yet led to a decrease in the youth unemployment. In 2013, it was still $12.6 \%$ close to the figure for 2009 , (United Nation, 2013). However, there are large variation between the world regions the problem is particularly severe in the Middle East and the North Africa where youth unemployment currently stands at an estimated $29.6 \%$ at $23.9 \%$, respectively. Youth unemployment rates are lower in the developed countries (17.5\%) and in the South East Asia (13.5\%), Latin America, (13.3\%), Sub-Sahara Africa (11.7\%), East Asia (10.0\%) and South Asia (9.6\%), (International Labour Organization, 2013). Demographic development is a key factor during high youth unemployment. Since the 1960s, global fertility may have declined dramatically, from an average of six to fewer than three births per woman (United Nation, 2013). This applies to almost all countries in Asia, Latin America and North Africa. Fertility has also decreased slightly in Sub-Saharan Africa, but remains at such a high level that there will be no slowing of population growth here for several decades (United Nation, 2013). The world's population is expected to increase by an estimated 2billion by mid-century, and most of this growth will occur in Sub-Saharan Africa, resulting in a corresponding large youth population (United Nation, 2013).

In Africa, youth unemployment has become a challenging issue both in economic and social term (Fashoyin, 2012). According to Fashoyin (2012), about 22million out of 40million African young job seekers has become increasingly jobless and fearful of their future opportunity. Given the current trend of annual labour market growth 
of $22.2 \%$, the challenge of youth unemployment still seem far from improving in the short time frame. This is because with this annual labour market growth, the number of youth in Africa is expected to double in 2045, which will make Africa the home of the most youth people in the world (Africa Economic Outlook, 2012). This high number of youth, coupled with existing weak and inadequate labour market institution, is thus expected to result in high persistent youth unemployment in the years to come. Especially, the situation of young women is a particular concern as they might face even higher rates of long term unemployment and joblessness basically for many gender related reasons (Fashoyin, 2012).

Nigeria is a country that is endowed with enormous resources, both human and materials. These resources are scattered across the six geo-political zones. However, it is the least in terms of comfortable standard of living. This cannot be unconnected with the level of unemployment the youth of Nigeria are faced with. Unemployment assumed a high proportion and it also seen as one of the causes of poverty in the country. This monster has been in the increase or is getting worst on daily basis as the number of graduate are increasing annually (Olaiya, 2013). Premium Time Mobile (2013) noted that "the rate of unemployment among Nigeria started to get worst in 2010. According to report, unemployment rate in Nigeria as of 2010 was $21.1 \%$. This figure within the shortest time possibly increase to $23.9 \%$ in 2011 even with the government poverty alleviation programmes such as National Poverty Eradication Program (NAPEP), National Directorate of Employment (NDE) and subsidy Re-Investment and Employment Program (SURE-P) to mention but a few. The rate of unemployment is alarming and scaring because of the disastrous consequences that accompany it. The rises in the level of unemployment is an indication that the measures adopted by the past administration are not yielding the desired objective (Ojo, 2008). For instance, according to National Population Commission report (2019), there are 51.8million Nigerian unemployed in the economy in 2011. This is a large population that could constitute a threat to the Nigerian economy, and thus, required adequate government attention (Olaiya, 2013).

Within the FCT, the relocating of the federal government seat of power from Lagos to Abuja has caused tremendous influx of people from 1991 till data. The high influx has caused a whole lot of social economic problems including overcrowding, competition and most importantly high unemployment (Ejaro, 2013). Abaji Area Council most like every other Area council has been noted with high rate of unemployment among the dwellers. This constant expansion of population size of FCT caused the creation of 2 additional area councils Kwali and Abaji in 1997 (Balogun, 2005). Hence, high unemployment rate can be largely attributed to poor performance of the government in managing its physical and human resources (Balogun, 2005).

Abaji Area Council is one of the six area council of the federal capital territory, Abuja. The area council is equally reach in human and material resources. Unfortunately, Abaji area council has large population of people ranging from those under employed to those unemployed. Unemployment in Abaji area council just like other area council in Abuja is said to be the highest, this has made life difficult especially, among the young people (youth) with enormous consequences (Daily trust, 2013). This clearly shows how disastrous unemployment is in the country because it has been on increase since 2006. There is no doubt that 2005-2006 demolition carried out in the Federal Capital by the then Minister MallamNasiru El-Rufai forced a whole lot of people from the city centre to the suburb area council such as Abaji. This has been noted to contribute largely to the rate of unemployment in the area council (Ejaro, 2013). There is also no doubt that some of that some of the social we are having in Nigeria and most especially in Abaji area council cannot be unconnected with the high level of unemployment. Such problems are conflict, kidnapping, armed robbery, prostitution, drug addiction and drunkenness to mention but few. This problem has negative impact of the socio-economic development of Nigeria at large and Abaji area council to be precise directly or indirectly. Conflict within the area council has been worsen by the rapid population growth annually and observed by national bureau of statistics (Daily Trust, 2013).

The research objectives pursued include:

- $\quad$ To study the trend of unemployment rate from 2000-2019 in Abaji Area Council.

- To examine the factors responsible for the unemployment in Abaji Area Council.

- $\quad$ To examine the effect of unemployment in the youth of Abaji Area Council. 


\section{THE STUDY AREA}

Abaji is one the satellite towns of federal capital territory Abuja. Lies very prominently along $A_{2}$ class of road network, at 96 kilometer south of the Abuja federal capital city (Balogun, 2005).Abaji Area Council is bounded by Latitude $08^{0} 25^{\prime} 00^{\prime \prime} \mathrm{N}$ and $08^{0} 35^{\prime} 55^{\prime \prime} \mathrm{N}$ and longitudes $06^{0} 45^{\prime} 00^{\prime \prime} \mathrm{E}$ and $06^{0} 55^{\prime} 51^{\prime \prime} \mathrm{E}$, with a total coverage of $138 \mathrm{~km}^{2}$. It's approximately $70 \mathrm{kl}$ from the international airport Abuja within easy reach of formula inland port of Lokoja, providing links by road to the south of Nigeria. Abaji Area Council has a land of 1,100square kilometers presently as at date and is quite suitable for agricultural activities and physical development (Balogun, 2005). Abaji Area Council is bounded in the south by Kogi State, North by Niger State, West by Niger State and South East by Kuje Area Council, North East Area by Gwagwalada Area Council, (Balogun, 2005).

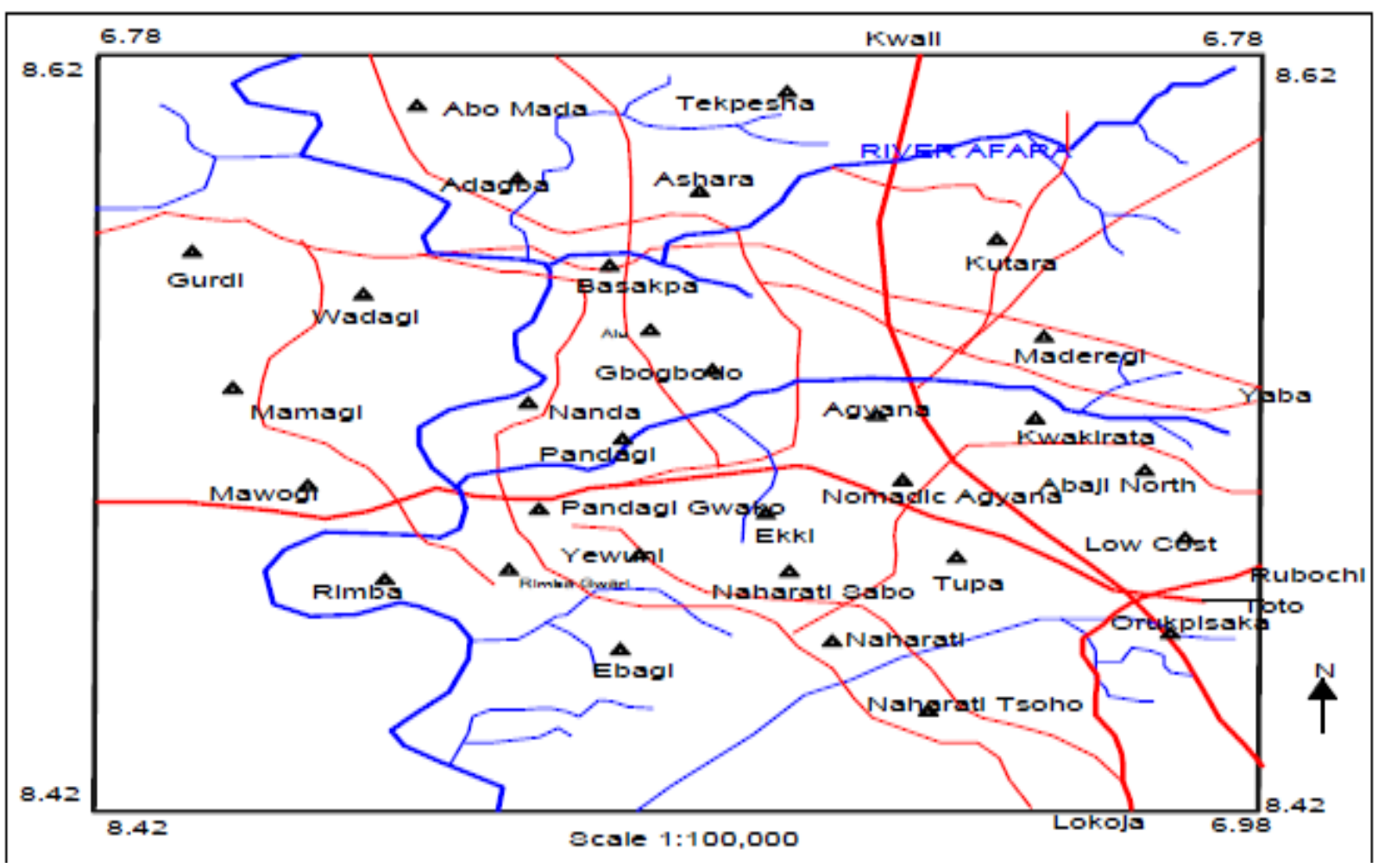

Fig. 1 map of Abaji Area Council showing study sits Source: Abaji Area Council 2019.

\section{LITERATURE REVIEW}

\subsection{Concept of Unemployment and Unemployment Rate}

Unemployment may be defined as a situation where some people who fall within the age of working population capable and willing to work, and are unable to obtain befitting work to do, (Anyaele, 2003). The problem of unemployment is becoming chronic and without any solution insight. It has constituted itself into one of the worst enemies of the people in this part of the world (Anyaele, 2003). According to Anyaele (2003), the problem of unemployment has been exacerbated by the prevalent retrenchment, unbridled, rural-urban migration as well as high population increase. Unemployment is a concept that has been subjected to many definitions depending on how the various authors tend to view it. According to Oxford Advanced Learners Dictionary of Current English (2005), unemployment refers to "state of being unemployed: Amount of unused labour". That is unemployment refers to labour that is not engaged or that is not put into use for productive purpose. Unemployment is also defined as "the percentage of the labour force that is without job" (Mundi 2013). Unemployment in other words is the total percentage of people who want to work but the work is not available. It refer to the number who have acquired 
the required knowledge and skills and are willing to work but the work is not available for them to do. These people are product of many institutions within and outside Nigeria (Olaiya, 2013). In the view of Olaiya (2013), any population of jobless people can said to be unemployment which has rendered many young men and women redundant. Beveridge (2004) one of the earliest authors in the subject matter quoted in Ojo (2008) defined unemployment as "the idleness of the man who depends on employment for a livelihood and cannot get the type of employment for which he is suited when he wants the kind of employment and he is fit for it". Thus, unemployment is a condition where a man has the ability to work to earn a living, but the job is not available for him. Such people may be those who have completed primary, secondary or tertiary who are roaming on the street searching for what to do for a living, (Ojo, 2008).

According to National Bureau of Statistics (2016), unemployment rate in Nigeria has risen from $12.1 \%$ in the first quarter of 2016 to $13.3 \%$ as at the end of the second quarter. The bureau stated this in the unemployment report which was released by the Statistician General of the Federation, in the report, the bureau stated that the number of people that were unemployed or underemployed increase from 24.4 million as at the end of first quarter of 2016 to 26.06 million persons by the end of the second quarter (NBS, 2016). The report reads in part, "the number of underemployed in the labour force (those working but doing memai jobs not commensurate with their qualifications or those not engaged in full time work and merely working for few hours) increased by 392,390 or $2.61 \%$ resulting in an increase in the underemployment rate to $19.3 \%$ in the second quarter of 2016 , from $19.1 \%$ in the first quarters of 2016". "during the reference period, the number of unemployed in the labour force, increased by $1,158,700$ persons, resulting in an increase in the national unemployment rate to $13.3 \%$ in the second quarter of the 2016 from $12 \%$ in the first quarter of 2016 . In view of this, there were a total of 26.06 million persons in the Nigeria labour force in the second quarter of 2016 that were either unemployed or underemployed compared to 24.5 million in the first quarter of 2016 (NBS, 2016). Unemployment rate is the proportion or percentage of the labour force or working population which is not employed at any given point in time (Anyaele , 2003). Unemployment rate is usually represented using the symbol " $U$ ", and it is usually calculated mathematically as;

$\mathrm{U} \quad=\quad$ Number of people unemployed $\times \underline{100 \%}$

Labor force 1

\subsection{Forms of Unemployment}

There are many types of categorization of unemployment in Nigeria for instance, Ojo (2008) in his book quote the "Human Resource management: theory and practice" discussed five types of unemployment, that have cut across many countries in the world particularly the developing countries, while Anyaele (2003) in an earlier study carried out on forms of unemployment summed it up to nine forms or types of unemployment.

- $\quad$ Structural unemployment

This is the type of unemployment whereby the qualification of a person is not adequate to meet responsibilities of his job or assignment. Structural unemployment comes as a result of certain factors such as: the technological displacement, lack of proper skills in the composition of demand, residency in depressed areas, changes in the structure of wages in relation to the pattern of demand and competitions of imports with domestic goods among others. The contributions of these factors to structural unemployment cannot be overemphasized. For instance, the introduction of technology such as computer has displaced many people in many organizations, especially banks and this has resulted in structural unemployment (Ojo, 2008).

\section{- $\quad$ Frictional unemployment}

Ojo (2008), also discussed frictional unemployment as the continuous flow of people from one job to another (in and out of employment). It is a situation where a person is out of one job and in search of another job. The time the person is staying without frictional unemployment which may be long or short. The major cause of frictional unemployment is not labour turnover for instance, new graduate spend some period of time searching for the night job that leads to frictional unemployment. Changing employment is not particularly easy especially where the level of unemployment is high such as Nigeria where the labour market is saturated (Ojo, 2008).

- $\quad$ Cyclical unemployment 
This is the type of unemployment that is caused by change in business conditions or during recession and depression. In other words, cyclical unemployment occurs due to the disequilibrium that leads to insufficient aggregate demand to purchase full employment output in a country. It is against this background that cyclical unemployment is called "demand deficient" unemployment. During recession and depression many employees usually lose their jobs (Ojo, 2008).

- $\quad$ Seasonal Unemployment

This kind of unemployment is based on the dictate of the season. Seasonal unemployment comes and goes with seasons of the year that dictates the demand of certain jobs. Seasonal unemployment usually concentrates in a particular season of the year which cease at another season. For example, labour demand increases during the wet season (due to planting, cultivation and harvesting). In addition, road construction is always out of place in the rainy season, albeit it depends on the terrain of the areas. Therefore, some workers are relieved of their work during the prevailing season (Ojo, 2008).

\section{- $\quad$ Residual Unemployment}

This type of unemployment occurs to people who are physically or mentally disabled that makes them to have low level of productivity, if at all any opportunity is open to them. Most people with certain mental and physically disability experiences residual unemployment because of their very low standard of efficiency or performance. These include blind, deaf and physically impaired people (Ojo, 2008).

\section{- Under-employment}

This is a solution whereby the potentialities of a worker are not fully utilized. There is financial, mental and physical under-employment. It is financial when the worker is not getting equal pay from the work he is doing: Mental when there is a mismatched between the works a person is doing and what he studied, and physically when the worker is underutilized (Anyaele, 2003).

\section{- Voluntary Unemployment}

This unemployment which is deliberate occurs when some people refuse to take up any paid employment or decide not to do any work. For example, some husbands may order their wives not to do any type of work but to stay at home as full time house wives (Anyaele, 2003).

\section{- Search Unemployment}

This arises when some people turn down offers of work in search of better paid employment. How long this search will last will depend on the prevailing economic situation in the country (Anyaele, 2003).

\subsection{Concept of Sustainable Development}

According to United Nations (2013), sustainable development is "a pattern of resource use that aim at addressing human needs while preserving environment so that these needs can be met not only in the present but also for generations to come". Hence, sustainable development is a kind of development that takes care of the basic needs of the present generation without compromising the interest of the next generation whether economic, political or social. Similarly, World Commission on Environment (2002) cited in Oyeshola (2008) defined Sustainable development as "development that meets the needs of the present without compromising the ability of the future generation to meet their own needs". Indeed the two definitions are similar in the sense that man's basic needs are virtually the same and revolve around economic, social, political and environmental needs. These needs are very crucial in the survival of mankind not only in the present generation but also the next generation. These needs entails food, housing, clothing, health, education, industrial and agricultural development, preservation and protection of the environment to enable people to live a comfortable life. Quality living is the essence of life which we struggle for on daily basis (Oyeshola, 2008). Sustainable development contains within it two key concepts:

- The concepts of the needs, in particular the essential needs of the world's poor, to which overriding priority should be given;

- The idea of limitations imposed by the state of technology and social organization on the environment's ability to meet present and future needs (United Nations, 2013). 
While the modern concept of sustainable development is derived mostly from the 1987 Brundtland Report, it is also rooted in earlier ideas about sustainable forest management and twentieth Century environmental concerns. As the concept developed, it has shifted focus more on economic development, social development and environmental protection for future generations. It has been suggested that "the term Sustainability should be viewed as humanity's target goal of human-ecosystem equilibrium (homeostasis), while sustainable development refers to the holistic approach and temporal processes that leads to the end point of sustainability (Onyeshola, 2008). " The concept of sustainable development has been argued and still suggested to criticism. What, exactly is to be sustained in sustainable development? It has been argued that there is no such thing as a sustainable use of a non-renewable resource, since any positive rate of exploitation will eventually lead to the exhaustion of Earth's finite stock; this perspective renders the industrial Revolution as a whole unsustainable. It has also been argued that the meaning of the concept has opportunistically been stretched from "conservation management" to "economic development", and that the Brundtland Report promoted nothing but a business as usual strategy for world development, with an ambiguous and insubstantial concept attached as a public relations slogan (Amos, 2010).

\subsection{Causes of Unemployment on Nigeria's Sustainable Development}

Unemployment in Nigeria cannot be unconnected with the following factors:

\section{- $\quad$ Poor Governance}

Inability of the government and the private sector to create jobs for the people coupled with the zeal of all educated people or graduates interest in white collar jobs (Terzungwe, 2013). Attempts made by the government to introduce programmes meant to reduce property and create employment opportunities have not yielded the desired result. Programmes such as; National Directorate of Employment (NDE) and National Poverty Eradication Programme (NAPEP). These programmes have not generated adequate employment opportunities. A report observed that during the last administration, unemployment rate grew from $21.1 \%$ to $23.9 \%$ from 2010 to 2011 (National Planning Commission, 2013). A report also stated that the rising rate of unemployment in the country is no fewer than 40 million Nigerians without jobs (National Bureau of Statistics, 2016).

\section{- $\quad$ Rapid Population Growth}

It is obvious that rapid population growth has played a significant role in the increase of unemployment level in Nigeria. Nwokwu, (2013), observed that Nigeria population based on 2006 Census was 140,431,790 with annual growth rate of $3.2 \%$. With this growth rate, the population could be over 180 million in the year 2020 . This is to larger extent has affected the increase of the labour force directly. It is against this background that Nigeria is said to be the most populous country in Africa. The rapid increase in population is not commensurate with the increase of the job opportunities. The population of the country is annually on the increase that if nothing tangible is not done, could be disastrous. Currently, Nigeria's Population is estimated at 167 million. With this rate of population growth, more than 150,000 Bachelor degree and Higher National Diploma graduates produced annually with no jobs for them to do (Isaiah, 2013).

\section{- $\quad$ Lack of government encouragement}

Terzungwe, (2013) also noted that lack of government encouragement for vocational and technical education as well as entrepreneurial development have contributed to unemployment in Nigeria. Vocation, technical and entrepreneur education are powerful tools that could empower the youth to be self-employed. Unfortunately, the vocational and technical schools we have in different parts of the country are not well equipped to instill students with the required skills. This cut across secondary and tertiary institutions. It is based on this our graduates are said to be unemployable because they lack vocational and entrepreneurial education that can make them selfreliance (Terzungwe, 2013).

\section{- Rural-Urban migration problems.}

Growing urban-labour force, as a result of rural-urban migration arises due to the need for white collar jobs, lack of social amenities in the rural areas and the high level of underemployment due to seasonal employment (Nwokwu, 2013). The inability of the of the government to provide infrastructural facilities in the rural areas such 
as good roads, electricity and recreational centres have forced youths to migrate to the urban areas. This has made farming to be the occupation of the elderly which of course is detrimental to food production in the country. This has been worsened by lack of access to agricultural facilities for them to engage in meaningful farming (Nwoku, 2013).

\section{- $\quad$ Increased Educational Institutions}

There is also the rapid exploision of educational institutions that directly increases the supply of man power in the labour market. In the 1960's there were only three universities in Nigeria located in the three regions namely; Ahmadu Bello University in Zaria, University of Ibadan, Ibadan and NnamdiAzikwe University, Nsukka. As at today, there are over 100 universities made up of Federal, State and Private, scattered in different parts of Nigeria, aside Secondary Schools, College of Education, Polytechnics and Monotechnics (Olaiya, 2013). The funny aspect of the most of these educational institutions particularly Universities is that they are producing unskilled graduate that are unemployable. It is against this that Olaiya (2013) noted that, "out of 4,000,000 youth that graduated from secondary and tertiary institutions annually, less than $20 \%$ can find white collar jobs". Only few of these graduates have skills that could enable them to be on their own or to be employable (Olaiya, 2013).

- $\quad$ Collapse of Industrial Sector

The collapse of "used to be viable" manufacturing or industrial sector has equally contributed to the high level of unemployment Nigeria is currently going through many industries in Kano, Kaduna and other cities in the country are nowhere to be found which rendered many people unemployed particularly the textile industries in Kano and Kadunna, it has been observed that "there are over 800 collapsed industries in Nigeria and over 37 factories have closed shops in 2009 especially in Kano and Kaduna (Nwokwu, 2013). It has to be noted that these collapsed industries are scattered across the country. It is unfortunate that a country blessed with fertile land suitable for cotton cultivation has allowed her textile industries to collapse. These were textiles in Kaduna and Kano that had thousands of employees (Nwoksu, 2013).

- $\quad$ Neglect of the Agricultural Sector

Neglect of agricultural activities such as farming has equally contributed to no small measure to Nigeria's unemployment. Farming in the 1960's and early 1970's was the major occupation that many Nigerians were engaged in particularly the youth. But with discovery of oil in the early 1970's farming was relegated to the background (Daily Trust, 2013). Agriculture in Nigeria has not been given the recognition it deserves if it is to make significant contribution to sustainable development of Nigeria in terms of jobs creation and providing food in abundance to Nigerians. It is on this note, Senator Victor Egba observed that "Agriculture has a lot of potentials that cannot only transform the natural economy but also tremendously impact the personal lives of the farmers, including the youth" (Nwokwu, 2013). Hence, poor agricultural policies meant to encourage youth to engage in farming have seriously contributed to the decay of agriculture in Nigeria that has made youth not to have encouragement to take farming as a reliable occupation (Nwokwu, 2013).

\section{- Corruption among Government Officials}

Corruption that has cut across all the levels or strata of government is not left behind in creating unemployment in Nigeria. This is obvious in the diversion of funds meant to generate employment opportunities, injustice to farmers among others. It is imperative to note that corruption to a larger extent deters investment because of the fact that it is disricentive to potential investors, aside distorting public expenditure and increase of overheads for running government businesses. Some of these monies diverted through corruption are not kept in Nigeria but in foreign banks abroad. Thus, it is not invested within to generate employment opportunities. According to Dalhatu (2012), Nigeria has lost almost a trillion naira to corruption in the last decade alone and this is money that could have been used to provide infrastructure and generate employment opportunities. Infact, a lot of revenue have been diverted into the personal pockets of top government offices (Nwokwu, 2013).

\subsection{Implications of Unemployment on Nigeria's Sustainable Development}

It is pertinent at this juncture to highlight some of the implications of unemployment in Nigeria's sustainable development. This is because unemployment has left much to be desired as far as sustainable development in Nigeria is concerned. One of the obvious implications of unemployment in Nigeria is poverty that is fundamental to Millennium Development Goals (MDG's). Poverty has become an order of the day in Nigeria because of the high level of unemployment among the youth. Poverty is a serious problem that has a lot of implication for lives 
of individuals, families and nation. Most of the unemployed youth cannot meet the basic need of their live that cannot guarantee Nigeria's sustainable development (Saanu, 2013). Saanu (2013) observed that many Nigerians cannot meet the basic needs of life because they have no jobs. Graduates are been churned out yearly in various institutions with dimmed prospects of getting job. The few jobs available are not based on merit or competence, rather on favoritism. The implication of unemployment on Nigeria's sustainable development therefore cannot be overemphasized because unemployed people cannot afford their basic things of livelihood. For example in the course of the disruption of oil production because of pipeline vandalism and associated crimes by movement for the emancipation of Niger Delta,(MEND, 2012). Fighting for resource control, Nigeria lost $\$ 15.8$ billion revenue that would have added impetus to Nigeria's sustainable development. Production could not continue because pipelines were vandalized or destroyed aside the number of people that died while struggling to siphon oil from broken pipes (Dalhatu, 2012).

Unemployment is a waste of human resources in view of the national resources put in training the unemployed. These resources could have been used in other area of five particularly the provision of infrastructure, no wonder, Ojo (2008) observe that, "the return to the various types of investment in human resources are unnecessary minimized by unemployment " Absence of social security in Nigeria also deprives the unemployed a share in the national income that makes the life of the unemployed miserable. Utilization of labour after investing a lot of resources on training is a colossal lost to the country. Unemployment is a condition where the available labour force is not used or utilized for the country to derive the benefit in national development. Therefore, in Nigeria as a whole, "the productive capacity of a significant portion of the labour force is unutilized "(Inigo, 2013). It is imperative to note that the essence of manpower training is to be able to make effective use if it so as to add value to the development of the country. Emergence of political thugs in so many parts of the country who are use as agent of harassment and intimidation of political opponents in places like Lagos, Gombe, Abia, Owerri, Warri, Onitsha and Rivers to mention but a few. It is pertinent to state that the Emergence of these "area boys" cannot be unconnected with the high level of unemployment being experienced in the country. The unemployed are ready to be employed for any kind of assignment as long as they are paid for it, because the unemployed also have needs which need to be met. This attitude is detrimental to the survival of the country because it is one of the major social problems affecting the growth and the development of this country in terms of sustainable development which of course we are yearning for (Saanu, 2013). Emergence of insurgency groups such as Boko Haram, Niger Delta Militants, innate cults to mention but a few. These deadly organisations came into existence as a result of unemployment the country is going through (Saanu, 2013). These terrorists groups as not only destroyed properties but also lives in places where they are operating such as Borno, Yobe, Adamawa, Kano, Kadunna, Nassarawa, River, Bayelsa, Delta and Edo among others (Saanu, 2013). There is no doubt that this negative attitude has directly affected the socio-economic development of the country. It is unfortunate a man has become a wolf to his fellow human being which has direct bearing on Nigeria sustainable development. People that are contributing to the development of the country are killed like ants. Government has also deployed a lot of funds to take care of the various attacks that should have been used in other areas for development (Dalhatu, 2012).

\section{MATERIALS AND METHODS}

A reconnaissance survey was carried out to have first-hand information about the study area. The data used in the study were sourced through primary source- derived directly from the field using questionnaire administration method as well as field interview. The questionnaire adopted an open-ended structure. Abaji Area Council has a population of 58,444 with a growth rate $7.2 \%$ as at 2006, (National Population commission, 2019). The population is estimated to have reached 117,135 by the end of the 2019 as projected by the National Population Commission (2019).

\subsection{Sampling size and sampling procedure}

According to Yamane (2000),

Sampling size $(\mathrm{R})=\frac{N}{1+N(0.05)^{2}}$ Where $\mathrm{R}=$ sample size, $\mathrm{N}=$ Population size $(117,135), \mathrm{R}=\frac{117,135}{1+(117,135)(0.05)^{2}}, \mathrm{R}=210$

The sample size $(\mathrm{R})$ is therefore 210 .

The reason for the choice of sample size is based on the population size. 


\subsection{Sampling Frame}

Table 1: Summary of Sample Frame Showing locations, population and Sample size

\begin{tabular}{|c|c|c|c|}
\hline $\mathbf{S} / \mathbf{N}$ & SETTLEMENTS & POPULATION & SAMPLE SIZE \\
\hline & Adagba & 5,518 & $\frac{5518}{89,143} \times 210=13$ \\
\hline & Abo mada & 4,240 & $\frac{4240}{89,143} \times 210=10$ \\
\hline & Nanda & 8,642 & $\frac{8642}{89,143} \times 210=20$ \\
\hline & Basakpa & 11,550 & $\frac{11550}{89,143} \times 210=27$ \\
\hline & Gbogboko & 10,450 & $\frac{10450}{89,143} \times 210=25$ \\
\hline & Kutara & 8,886 & $\frac{8886}{89,143} \times 210=21$ \\
\hline & Maderegi & 2,222 & $\frac{2222}{89,143} \times 210=5$ \\
\hline & Pandagi & 8,450 & $\frac{8450}{89,143} \times 210=20$ \\
\hline & Yewumi & 6,881 & $\frac{6881}{89,143} \times 210=16$ \\
\hline & AbajiNorth & 5,804 & $\frac{5804}{89,143} \times 210=14$ \\
\hline & Tupa & 7,800 & $\frac{7800}{89,143} \times 210=18$ \\
\hline & Ebagi & 3,899 & $\frac{3899}{89,143} \times 210=9$ \\
\hline & Orukpisaka & 4,801 & $\frac{4801}{89,143} \times 210=12$ \\
\hline & Total & 89,143 & 210 \\
\hline
\end{tabular}

Source: Author Survey, 2019

\subsection{Data Presentation and Statistical analysis}

The research adopts various methods of data presentation and analysis; simple bar graphs, pie charts and tables.

The chi-square was employed in testing the hypothesis. It is expressed mathematically as:

Chi-square $\mathrm{x}^{2}=\sum^{\mathrm{k}}(0-\mathrm{E})^{2}$

Where; $\mathrm{O}_{\mathrm{i}}=$ observed value, $\mathrm{E}_{\mathrm{i}}=$ Expected values

$$
\mathrm{i}=1 \quad \mathrm{E}_{\mathrm{i}}
$$




\section{RESULTS AND DISCUSSION}

5.1 Nature and Trend of Unemployment in Abaji Area Council.

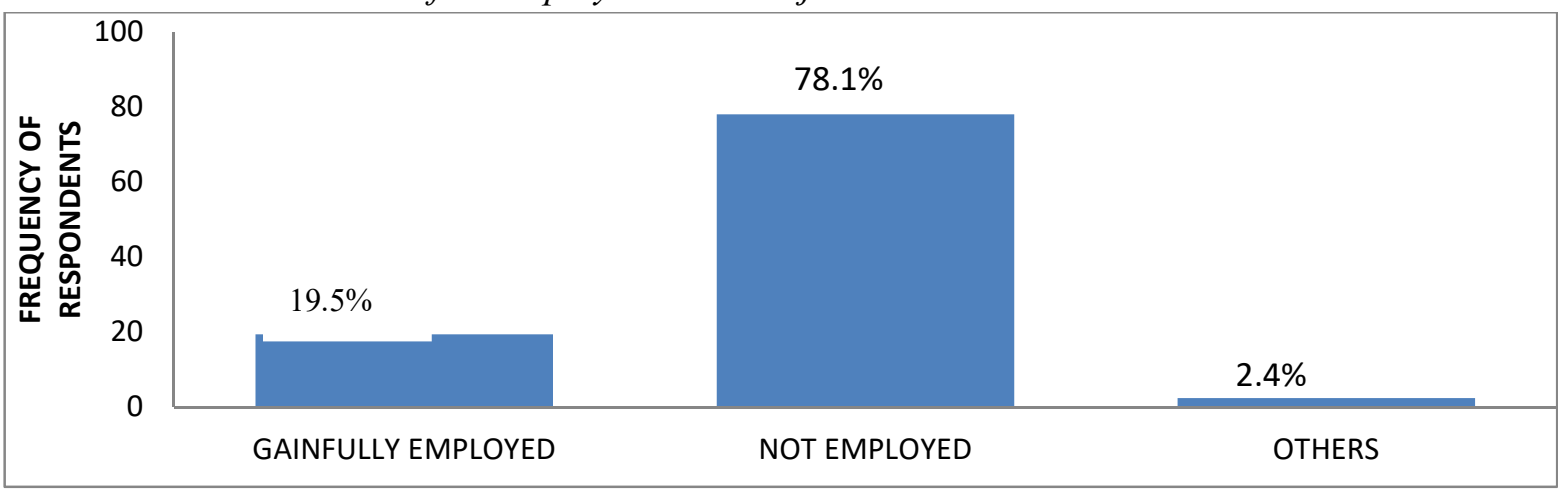

Fig 2: Showing Respondents Employment Status

Figure 2 shows that $19.5 \%$ of the respondents are gainfully employed, i.e either civil servant or employed in some sort of firms or organization, $78.1 \%$ of the respondents which represents are neither employed nor unemployed but form part of the mobile labour, they include site servers, bus conductors and markets. There next source of Job is not guaranteed.

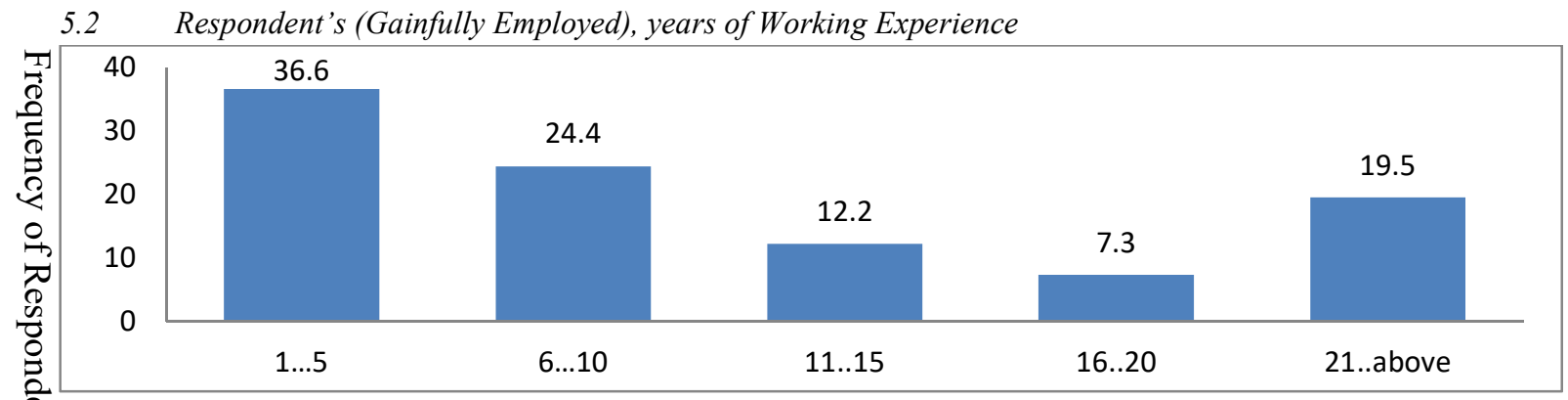

Fig 3: Showing Respondents Years of Working Experience

Figure 3 above is showing the frequency and percentage (For those who agreed to be gainfully employed). $36.6 \%$ of the 41 respondents who are gainfully employed have worked for a period of $1-5$ years, $24.4 \%$ of the respondents have worked for $6-10$ years, $12.2 \%$ have working experience was accumulated by $7.3 \%$ of the 41 respondents which $19.5 \%$ of the respondents gainfully employed fell within 21 - above years of working experience.

5.3 Periods schedule of Payment

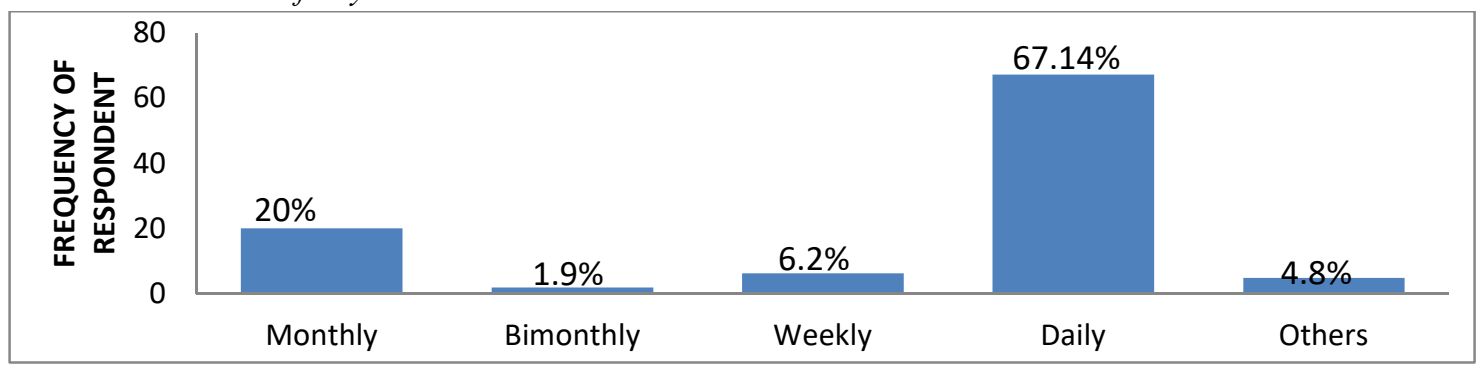

Fig. 4: Showing the schedule of Payment of the Respondents 
Figure 4 show that $20 \%$ of the respondents depends heavily on monthly income, this relates mainly to those whom are gainfully employed. $1.9 \%$ of the respondents earn bi-monthly as their wages comes in every forth night, $6.2 \%$ of the respondent gets their wages on a weekly basis, $67.4 \%$ of the respondents get paid daily, this constitute mainly the farmers, trades and other vocational worked such as mechanic, electrician, bricklayers among others. While $4.8 \%$ of the respondents do not have a specific time scare of being paid, they include agents that deal on landed properties, mobile labourers among others.

5.4 Salary/Wage Scale of Respondents

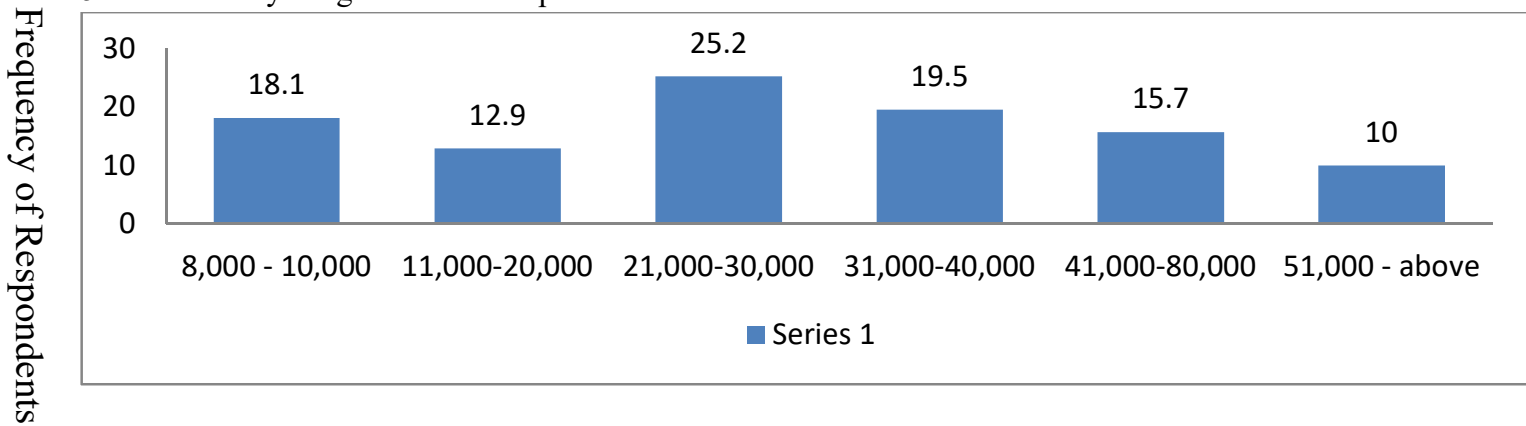

Fig. 5: Showing Wages/Salary Scale of Respondents

Figure 5 above shows that $18.1 \%$ of the respondents earn between $\# 5,000-\# 10,000,12.9 \%$ of the respondents earn between $\# 11,000$ - \#20,000, 25. 2\% of the respondents earn $\# 21,000$ - \#30,000, 19.5\% of the respondents earn between $\# 31,000$ - \#40,000, 15.7\% of the respondents earn between $\# 41,000$ - \#50,000, While 8.6\% of the respondents earn between $\# 51,000$ and above. The table clearly shows that bulk of the population earns below $\# 30,000$ as salary/wages.

\subsection{Respondent's Monthly Expenses Coverage}

Table 2; showing respondent's monthly expenses cover

\begin{tabular}{|l|l|l|}
\hline $\begin{array}{l}\text { Expense Cover (Does year salary/wages meet your monthly } \\
\text { expenses) }\end{array}$ & Frequency & Percentage (\%) \\
\hline Yes & 56 & $26.7 \%$ \\
\hline No & 143 & $68.1 \%$ \\
\hline Others & 11 & $5.2 \%$ \\
\hline Total & $\mathbf{2 1 0}$ & $\mathbf{1 0 0 \%}$ \\
\hline
\end{tabular}

Source: Researcher field Survey, 2019

Table 2 above reveals that, $26.7 \%$ of the respondents are of the opinion/responses, reasons ranging from small family one or still single, adjustment within the income amongst other reasons. $68.1 \%$ responded that their monthly income not commensurate or meet up with their expenses, $5.2 \%$ neither agree that their monthly income is enough nor not commensuration to their monthly expenses due to fluctuations in their monthly earning and their expenses. Interaction with the respondents reveal that, majority of the respondent whose monthly income do not match up to their expenses undertake part time jobs, engage in extra hour at work, and rely on previous savings to argument their expenses. 


\subsection{Trend of Unemployment Rate in Abaji Area Council}

Table 3 Showing Trend of Unemployment Rate

\begin{tabular}{|l|l|l|}
\hline Trend of Unemployment rate & Frequency & Percentage (\%) \\
\hline Increasing & 128 & $60.9 \%$ \\
\hline Decreasing & 41 & $19.5 \%$ \\
\hline Fluctuating & 22 & $10.5 \%$ \\
\hline Static & 13 & $6.2 \%$ \\
\hline Others & 6 & $2.9 \%$ \\
\hline Total & $\mathbf{2 1 0}$ & $\mathbf{1 0 0 \%}$ \\
\hline
\end{tabular}

Source: Researcher field survey, 2019

Table 3 shows that $60.9 \%$ of the respondents are of the view that the rate of unemployment in Abaji Are council is increasing, $19.5 \%$ of the respondents opined that the rate of unemployment is decreasing due to the introduction of basic amenities as well as infrastructures in Abaji Area council, 10.5\% of the respondents agreed that the unemployment rate is fluctuating, while $6.2 \%$ is of the view that it is static. $2.9 \%$ of the respondents have no clear idea of the unemployment rate in Abaji area Council, reasons ranging from illiteracy, non-chaplaincy or are strangers. The table show clearly that, the unemployment rate of youths in Abaji Area Council is increasing.

\subsection{Causes of Unemployment in Abaji area Council}

Table 4 shows the factors responsible for unemployment in Abaji council

\begin{tabular}{|l|l|l|l|l|l|l|l|}
\hline Causes of Unemployment in Abaji Area Council & SA & A & D & SD & Total & Mean & Remarks \\
\hline High level of illiteracy & 26 & 32 & 31 & 11 & 100 & 2.7 & Disagreed \\
\hline Lack of technical know-how & 56 & 22 & 18 & 4 & 100 & 3.3 & Agreed \\
\hline Tribal sentiment and religious affiliations & 12 & 11 & 48 & 29 & 100 & 2.1 & Disagreed \\
\hline Political affiliation in securing job & 68 & 21 & 8 & 3 & 100 & 3.5 & Agreed \\
\hline Poor level of education & 45 & 21 & 18 & 16 & 100 & 2.9 & Disagreed \\
\hline Population explosion in Abaji Area Council & 72 & 13 & 14 & 1 & 100 & 3.5 & Agreed \\
\hline $\begin{array}{l}\text { Lack of basic infrastructures to facilitate the development of } \\
\text { industries in Abaji Area Council }\end{array}$ & 37 & 36 & 15 & 12 & 100 & 2.9 & Disagreed \\
\hline
\end{tabular}

Source: Researcher field survey, 2019

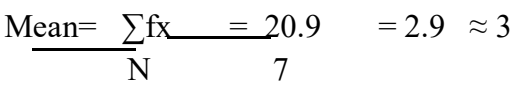

Analysis of tables 4 shows that $58 \%$ of the respondents are of the opinion that high level of illiteracy is responsible for unemployment in Abaji Area Council, 78\% of the respondents are of the view that lack of technical know-how is also responsible for unemployment in Abaji Area Council. The table reveal that only $23 \%$ of the respondents attest that tribal sentiment is responsible for unemployment in the area hence making that factor to be baseless and uncommon $65 \%$ of the respondents attest that political affiliation in securing job is responsible for unemployment in the area, hence those without God fathers and politically accessible leaders are not easily favoured during employment. $89 \%$ of the respondents are of the opinion that inadequate industries and lack of job opportunity has contributed hugely to high rate of unemployment in Abaji Area Council, where there are no industries, factories or firms to employ the people there will be competition for the available ones hence high unemployment rate $66 \%$ of the respondents are of the opinion that poor level education amount to high unemployment in the area. Lack of well-trained or educated youths affects their job opportunity in the area. $85 \%$ of the respondents are opinion that population explosion over the years have strongly contributed to high rate employment in the area. As resettlement of towns within the Federal Capital Territory, Immigrants from rural areas as well as those affected by the Mallam Nasir El-Rufia demolition exercise of 2004-2006 in the Federal Capital territory of illegal structures for development, Abaji area Council have gained massive population. As population increases there is pressure on available jobs creating completion as well as large scale structural unemployment $73 \%$ of the respondents are of the view that lack of basic infrastructure to facilitate the development of industries in Abaji Area Council is also responsible for high rate of unemployment in the area. 


\subsection{Effects of Unemployment in Abaji Area Council}

Table 5 Show the effects of unemployment in Abaji Area Counci.

\begin{tabular}{|l|l|l|l|l|l|l|l|l|}
\hline Effects of Unemployment in Abaji Area Council & SA & A & D & SD & Total & Mean & Remarks \\
\hline Increase in crime rate in Abaji Area Council & 42 & 40 & 15 & 3 & 100 & 3.2 & Agreed \\
\hline $\begin{array}{l}\text { High rate of unemployment leads to increase in natality rate } \\
\text { (child birth) in Abaji Area Council }\end{array}$ & 20 & 17 & 52 & 11 & 100 & 2.5 & Disagreed \\
\hline $\begin{array}{l}\text { High unemployment rate result to pressure on available basic } \\
\text { amenities in Abaji Area Council }\end{array}$ & 38 & 51 & 7 & 4 & 100 & 3.2 & Agreed \\
\hline $\begin{array}{l}\text { Unemployment result to hunger and poverty among the youths of } \\
\text { Abaji Area Council }\end{array}$ & 56 & 38 & 6 & 0 & 100 & 3.5 & Agreed \\
\hline $\begin{array}{l}\text { The socio-economic status of Abaji Area Council is downgraded } \\
\text { by high rate of unemployment in the area. }\end{array}$ & 28 & 43 & 20 & 9 & 100 & 2.9 & Disagreed \\
\hline $\begin{array}{l}\text { Unemployment leads to loss of confidence on the leadership of } \\
\text { the government of Abaji Local government chairman }\end{array}$ & 40 & 52 & 6 & 2 & 100 & 3.3 & Agreed \\
\hline
\end{tabular}

Source: Researcher field survey, 2019

$$
\underbrace{\text { Mean }=\sum \mathrm{fx}=}_{\mathrm{N}} \underset{6}{18.6}=3.1
$$

Table 5 shows that $82 \%$ of the respondents attest that lack of unemployment in Abaji Area Council leads to an increase in crime rate. The vibrant, young and able bodied youth that cannot get a befitting job might end up becoming notorious and easily lured to commit crime. $37 \%$ of the respondents only agreed that high rate of unemployment leads to an increase in child birth as they tend to spend more hours at home with their wives, hence using sex to compensate themselves. $89 \%$ are of the view that high rate of unemployment result to pressure on available basic amenities in the area, this is because the non-working youth will spend more time at home consuming higher amount of energy. 94\% attest that unemployment brings about hunger and poverty. The percentage level shows that there is high level of hunger and poverty in the area. $97 \%$ of the respondents believe that, unemployment among the youth of Abaji Area Council increase the dependency ratio. The youth that is supposed to carter for the young and aged group is forced to depend on one another and the aged ones, hence increasing the dependency ratio for those who ought to have been resting from civic service. $71 \%$ agrees that the high rate of unemployment in the area have led to the downgrade of the socio economic status of Abaji Area Council hence scanning away both indigenous of foreign investors that should have come to the area. $92 \%$ of the respondents attest that have caused the people to loose trust and confidence in the government of the area.

\subsection{Hypothesis Verification:}

$\mathrm{HO}_{1}$ : There is no significant difference in the effects of unemployment among the youth in Abaji Area Council.

\begin{tabular}{|l|l|}
\hline Effect of Unemployment in Abaji Area Council & \% Acceptance \\
\hline Increase in crime rate (A) & 82 \\
\hline Increase Child Birth (B) & 37 \\
\hline Pressure on infrastructures (C) & 89 \\
\hline Under-development of the area (D) & 92 \\
\hline Increase hunger and poverty € & 94 \\
\hline Increase in dependency ratio (F) & 97 \\
\hline Downgradual Socio-economic status (G0 & 71 \\
\hline Loss of Confidence on the leadership (H) & 92 \\
\hline
\end{tabular}


$\mathrm{X}^{2}=33.81$ (Calculated Value)

\begin{tabular}{|l|l|l|l|l|l|}
\hline Effects of Unemployment & $\mathbf{O}$ & $\mathbf{E}$ & /O- E/ & (O-E)2 & (O- E)2 \\
\hline A & 8.2 & 81.75 & 0.063 & 0.063 & 0.0008 \\
\hline B & 37 & 81.75 & -44.75 & 2002.56 & 24.50 \\
\hline C & 89 & 81.75 & 7.25 & 52.56 & 0.64 \\
\hline D & 92 & 81.75 & 10.25 & 105.06 & 1.29 \\
\hline F & 94 & 81.75 & 12.25 & 150.06 & 1.84 \\
\hline G & 97 & 81.75 & 15.25 & 232.56 & 2.84 \\
\hline H & 71 & 81.75 & -10.75 & 115.56 & 1.41 \\
\hline & 92 & 81.75 & 10.25 & 105.06 & 1.29 \\
\hline
\end{tabular}

From the table of percentage values for the Chi-square distribution, the critical valve of $X^{2}$ at 0.05 for the 7 degrees of freedom is 14.067 . Since the calculated value $\mathrm{X}^{2}$ of 33.81 is greater than the critical valve 14.067 , the null hypothesis is (Ho) is rejected while the alternative hypothesis is accepted. Hence, there is significant difference in the effects of unemployment among the youths in Abaji Area Council. This is because not all youths in Abaji Area Council are susceptible to the same effects mentioned earlier, as respondent's status differ.

\section{SUMMARY AND CONCLUSION}

Abaji Area Council is one of the six area council in federal capital Territory, Abuja. The movement of the seat of power from Lagos to Abuja in 1991 is expected to improve the economic and social status of the F.C.T. But not all area council have highly benefited from this. The major challenge or factor militating against the socioeconomic development in most area council of the F.C.T such as Abaji Area Council, is the high influx of people into the FCT since 1991. Also, resettlement of people living within the region, demolition exercise within the FCT at various time have caused population explosion to the boundary regions and suburb areas such as Abaji Area Council. These created competition and pressure on available jobs leading to high rate of unemployment in the area.

The planning and development of the Federal Capital Territory was not done considering all area councils simultaneously, rather, focus and attention were given to certain areas that serve immediate need. This resulted to little or no infrastructure in Abaji Area Council and in return led to inadequate industries and firms to cope with this ever increasing population in the area. The government also failed in consistent empowerment of the youth, as most public funds were embezzled and the government made little or no effort to recover the loot. The populace has not been empowered adequately in areas; education, finance and exposure, hence resulting to gross rate of unemployment amongst the youth of Abaji Area Council.

\section{RECOMMENDATIONS}

The following recommendations are proffered to solve the problems of youth unemployment in the FCT, with Abaji Area Council as case study.

i. The business sectors should be enabled through tax reduction and tax holidays to reduce operating costs.

ii. Increase graduate skills and make them more a problem solver, creators, entrepreneurs, and innovators.

iii. Reformation of educational system, by ensuring that student learns more practical real life issues and problems than theories that are neither applicable nor relevant.

iv. Vocational trainings should be encouraged in Abaji Area Council and possibly empower those interested.

v. Reformation of agricultural sector through modernization of the sector, to attract the young graduates to engage in sector.

vi. The youth and graduate should be trained in the use of some agricultural technology and exposed to improve and modern practice.

vii. Government should invest in the industrial sector this will lead to increase in capital formation and Growth of small and medium scale industries that has the potential to employ hundreds of thousand graduate in Abaji Area Council.

viii. Small and Medium size firms should have access to information on managing business to prevent failure. 
ix. Government should encourage healthy competition in the industrial sector leading to more investment and employment in Abaji Area Council.

x. A healthy partnership should exist between the government and the private sector to establish manufacturing plants in Abaji Area Council.

xi. Government should adopt policy of decentralization of the industrial sector to increase employment generation in the area council.

xii. Government should invest heavily. In Infrastructural development in Abaji Area Council.

xiii. Government should increase its capital expenditure especially in the area of transportation - building good roads networks, subsidizing transportation cost for easy access of raw materials by the industrial sector in Abaji Area Council.

xiv. Electricity distribution should be improved. Most businesses are collapsing because of high cost of Business resulting from poor power supply in Abaji Area Council.

xv. The communication system should be improved. A better internet connection in the country will improve the presence of most business online.

xvi. Proper evaluation and monitoring of government spending on infrastructures will save the area council from embezzlement of funds.

xvii. Recurrent expenditure should be drastically reduced. This currently takes over three quarters of government spending in the nation at large.

xviii. Subsidizing education at all level will reduced the pressure on students to meet up with the payment.

xix. Unemployed youth in Abaji Area Council should be trained on various skills acquisition. Nigeria youth lack skills and this is the major cause of unemployment in Abaji Area Council.

xx. Above all governments should either creates job or provide enabling environment for private sectors to create the jobs.

\section{REFERENCES}

African Economic Outwork (2012). Unemployment among African youths in the contemporary times. AEO journals 40(2), 91-120

Amos E. (2010). Urban unemployment situation in Nigeria, E.O. Ezeani and N.N.Elekwa (Eds). Issues in urbanization and urban administration in Nigeria, Enugu, jamo, Enterprises. PP 154-167.

Anyaele A. (2003). Youth unemployment, poverty a time bomb for country leadership, Wednesday 27 august National Bureau of statistics annual socio-economic report

Balogun O. (2005). High population growth in the Federal Capital Territory and the alarming effects on the economy journal of Social Sciences v(18); 14-15.

Balogun O. (2008). The location, size and position of the Federal Capital Territory (FCDA) Journals. November 28. V.(28)

Beveridge A. (2004). Youth employment and implications for stability of democracy in Nigeria

Daily trust (2013). High unemployment among the youth of Abaji Area council hits peak. Saturday 28th

Dalhatu H. (2012). The causes and effects of unemployment on the socio-economic development of Nigeria, Retrieved from daily trust, Com 08/11

Dawan P. (2006). Regional disposition and the indigenous dwellers of the Federal Capital Territory of Social Sciences.

Ejaro S.P. (2013), land accessibility problems in Nigeria : A case study of Gwagwalada. Research journal of Social Sciences. And Management, volume :02, page 160.

Fashoyin A. (2012), youth unemployment and national directorate employment self-employment programs. Nigeria Journal of Economics and Social studies, volume (41), page 81-102.

Inigo O. (2013). Manpower development and the fading job security in the Nigeria Territory. Journal of Social and economic development. V (18); 221-226.

International labour organization (2013). The structure mobility of labour among undeveloped nation of the world. I L O Journals, volume;59 page 12-21.

Isaiah A. (2013). Unemployment among youth of Nigeria society, journal of demographic studies V (14), 214 215. 
Kinsella T. (2015): Dependency ratio among the working population in West Africa countries. Jornals of NBA (national bureau of statistics ). Mundi R. (2013), the population structure and distribution within the Federal Capital Territory Jornal of Social Sciences.

Morgan H. (2004). Challenge of pressure population and the environmental consequences, journal of environmental Sciences.

National Bureau of statistics. (2016). Statistical news; labour force statistics, no. 476 Abuja. The NBA national population commission and ICF macro,(2009). Nigeria demographic and health survey (2008) abuja, Nigeria. National population commission and ICF macro.

National population commission (2012), population growth report, the adverse effects on the structural employment. NPC journals. V (28), page (18).

Nwoku O. (2013). Population explosion ; a major case for unemployment in Nigeria. Retrieved from vanguard. Com $/ 2012 / 08 /$.

Ojo a. (2008), youth unemployment in Nigeria : some implications for the third Millennium. Global Journal of Social Sciences volume 2(1), page 21-26.

Olaiya H. (2013), Harsh operating environment claims 834 Nigeria manufacturing companies investigation. Sunday punch, Saturday, 31 October.

Oyeshola o. (2008), development crisis of power supply and implications for industrial sector in Nigeria, journal of Tribes and Tribals,6(2), 83-92.

Premium Time Mobile, (2013). The rate of unemployment among Nigerians. Daily time. Page 15. February 22nd.

Saanu A (2013). Implications of unemployment on Nigeria sustainable development. Journal of NBS (National bureau of statistics ). Volume (15), page 18-21.

Terzungwe H. (2013). Entrepreneur ship development a panacea for unemployment reduction in Nigeria, journal of emerging trends in economics and Management Sciences (JETEMS) 2(4); 251-256.

United Nations (2013), Global increase of unemployment rate among developing countries. United Nations journal. Volume ;152, page 36-39.

World commission on environment, (2002). World environment, population and alarming rate of unemployment across the world. WCE journals. Volume (8), page 18-1 